Original Paper $\quad$ http://ajol.info/index.php/ijbcs $\quad$ http://indexmedicus.afro.who.int

\title{
Qualité physico-chimique des eaux littorales de la partie Sud-Ouest du Lac Albert, RD Congo
}

\author{
Kasigwa Dieudonné CIWANINE ${ }^{1 *}$, Lonze Joël KATHO², Busanga Alodor KANKONDA ${ }^{3}$ \\ et Jean-Claude MICHA ${ }^{4}$ \\ ${ }^{1}$ Université Officielle de Bukavu, Faculté des sciences, Département de Biologie, RD Congo. \\ ${ }^{2}$ Division d'Agriculture, Pêche et Elevage, Province d'Ituri, RD Congo. \\ ${ }^{3}$ Université de Kisangani, Faculté des sciences, Département d'Hydrobiologie, RD Congo. \\ ${ }^{4}$ Environmental Biology Research Unit (URBE), University of Namur, Belgium. \\ *Auteur correspondant; E-mail : cikwadieudonne@ gmail.com
}

\section{RESUME}

Le lac Albert est moins étudié en ce qui concerne l'évolution de la qualité de ses eaux. L'objectif de cette étude était de contribuer à la connaissance de quelques paramètres physico-chimiques des eaux littorales de la partie Sud-Ouest du lac Albert. Pour y parvenir, nous avons utilisé un kit multi-parameter AZ8603 pour le prélèvement, in situ, du $\mathrm{pH}$, de l'oxygène dissous, de la conductivité électrique et de la température pendant un cycle de 24 heures à intervalle de 3 heures durant une année. Il ressort de cette étude que les moyennes de température, conductivité, oxygène dissous et $\mathrm{pH}$ sont respectivement de $29,07^{\circ} \mathrm{C}, 631,65 \mu \mathrm{s} / \mathrm{cm}, 4,8 \mathrm{mg} / \mathrm{l} \mathrm{et}$ 8,01 . La concentration en oxygène dissous était plus élevée le jour que la nuit. La différence non significative de température entre le cycle diurne et nocturne montre que l'activité photosynthétique est l'élément explicatif de l'augmentation du taux d'oxygène dissous. Les mois d'avril et de mai se sont distingués par une forte température et une baisse de la concentration en oxygène dissous. Ceux de mars, août, octobre et novembre ont été marqués par une conductivité élevée corrélée positivement à la température.

(C) 2020 International Formulae Group. All rights reserved.

Mots clés : Eaux, lac Albert, physico-chimie, variation nycthémérale.

\section{Physico-chemical of coastal waters of the South-Western part of Albert Lake, DR Congo}

\begin{abstract}
The Albert Lake is barely investigated with regard to the evolution of the quality of its waters. The objective of this study was to contribute to the knowledge of some physico-chemical parameters of the coastal waters of the South-Western part of the Albert Lake. To reach the above objective, a kit multi AZ8603 parameter was used to record, in situ, the $\mathrm{pH}$, the dissolved oxygen, the electric conductivity and the temperature during a cycle of 24 hours, with 3 hours interval. This was done during a year. This survey evidenced that the averages of temperature, conductivity, dissolved oxygen and $\mathrm{pH}$ were respectively $29.07{ }^{\circ} \mathrm{C}, 631.65 \mu \mathrm{s} / \mathrm{cm}, 4.8 \mathrm{mg} / \mathrm{l}$ and 8.01. The concentration of dissolved oxygen was higher during the day as compared to its concentration in the night. The slight difference of temperature between the diurnal and nocturnal cycle showed that the
\end{abstract}


photosynthesis activity was responsible of the increase of the dissolved oxygen rate. The months of April and May were characterized by relatively higher temperature and a lower concentration of dissolved oxygen. Those of March, August, October and November showed higher conductivity correlating positively to the temperature. (C) 2020 International Formulae Group. All rights reserved.

Keywords: Waters, Albert Lake, physico-chemistry, circadian variation.

\section{INTRODUCTION}

The Albert Lake is one of the biggest lakes of the rift Albertin with a surface estimated at $5600 \mathrm{~km}^{2}$. It is classified among the polymictique lakes and is therefore provided with oxygen in depth (maximal depth $58 \mathrm{~m}$ ). This type of structure implies notably that the planktonic biomass and the nutriments contained in the ecosystem are available in the whole column of water because of the dynamics of circulation of the water masses, mainly due to winds. This brewing should responsible of the productivity increase of the lake.

An aquatic system is influenced by the surrounding biotic and abiotic factors which allow making the classification of a lake. Water quality is one of the major problems of environmental health which developing countries are facing (Montgomery and Elimelech, 2007). In a lake, the change in concentration of the dissolved oxygen, of the temperature and the $\mathrm{pH}$ during 24 hours, is strongly dependent on the autotrophic and heterotrophic activities, and it is in interrelationship with the contribution in nutriments during a diurnal cycle (Sabater et al., 2000).

In most studies, the physico-chemical parameters such as the dissolved oxygen, the temperature and the $\mathrm{pH}$ are taken in a punctual manner, and often only during the day while their concentration is increased due to the strong sunshine and photosynthetic activity (Wetzel, 2000; Moatar et al., 2009). To avoid having the skewed conclusions, Wetzel and Likens (2000), Villeneuve et al. (2006) recommend to make repeated and cyclic records ( 24 hours) of the $\mathrm{O}_{2}$, the temperature and the $\mathrm{pH}$ in order to relativize the diagnoses established from punctual measurements and therefore to warn or to anticipate possible contentious in the evolution of the ecological state of an aquatic system.

Only few studies have been done on the environmental parameters of the Albert Lake in its South Western part. The recent and general available data are those provided by Hecky and Kling (1987), Ssentongo (1987); they show that the conductivity of the Edouard lake varies between 900-925 Ms/bas, the $\mathrm{pH}$ between 8.5 to 9.3 with an average temperature of $26{ }^{\circ} \mathrm{C}$ while the Albert Lake has a temperature varying enters 27.5 and $29^{\circ} \mathrm{C}$. These reports do not bring out the other parameters studied in the present work. Thus, this lake has a gap of information about water quality in its Congolese part because the available data were recorded in 1987 (Ssentongo, 1987) and were only for the Ugandan part.

Thus, this survey aimed at bringing out the diurnal and yearly variation of the physicochemical parameters of the surface waters of the Albert Lake.

\section{MATERIALS AND METHODS Sampling site and methods}

The Albert Lake is located in the Northern part of the West arm of the Rift valley in East Africa between $2^{\circ} 15^{\prime}$ and $1^{\circ} 00^{\prime}$ North of latitude, and also between $30^{\circ} 21^{\prime}$ and $31^{\circ} 25^{\prime}$ East of longitude. It borders Uganda and the D.R. Congo, an alluvial plain joins the Victoria Nile and the Albert Nile. The West coast, along the D R Congo, is characterized by $2000 \mathrm{~m}$ of scarps. The coast South is marked by swamps, in particular of papyrus, that dominates the delta of the Semliki river joining the Edouard Lake to the Albert Lake.

The sampling site was in Kasenyi, situated in the coastal part of the lake, at a distance of $30 \mathrm{~m}$ from the strand (Figure 1). The sampling in situ was done at a depth of less than $1 \mathrm{~m}$. This site was chosen because the easy accessibility during the 24 hours of a day, the 
safety of the equipment during the night experiments, and also its distance from the embarking and landing places of the fishers.

The record of the physico-chemical parameters was done two times a month (Wednesday of the first and the third weeks). The circadian cycle was subdivided by 8 . Therefore, the record of the data was done in situ made every 3 hours $(6 \mathrm{H}, 9 \mathrm{H}, 12 \mathrm{H}, 15 \mathrm{H}$, $18 \mathrm{H}, 21 \mathrm{H}, 24 \mathrm{H}, 3 \mathrm{H}$ ). During the working day, the probes of the multi-parameters device Mark AZ 8603 (Figure 2) were dived at $1 \mathrm{~m}$ of depth for some minutes until the numbers displayed on the screen of the device stabilized.

- Concentration of dissolved oxygen: expressed in $\mathrm{mg} / \mathrm{l}$ and in percentage of saturation. It is considered as an important parameter of aquatic environment and is a limiting factor for every species. It also gives the idea on the working of the aquatic environment. According to Laboulle (2010), the concentration in $\mathrm{mg} / \mathrm{l}$ corresponds to the expression of any other solution of water such as mineral salts, an indicative but raw value. The concentration in percentage is more expressive and is equivalent to the ratio between the concentration of oxygen really present and the theoretical maximal concentration of oxygen expected at the temperature of measurement. The concentration of the oxygen in water depends also on the air pressure, the temperature, and the photosynthesis.

- $\mathrm{pH}$ (potential in hydrogen): in the natural media, the weak $\mathrm{pH}$ corresponds to the deficit in oxygen and to the weak primary activities whereas the basicity generally superior to 8 denotes a strong photosynthetic activity. A good piscicultural water must have a $\mathrm{pH}$ ranging from 6.5 to 9 (Hade, 2003).

- The electric conductivity: gives an idea on the capacity of water to conduct the electric current. It is a function of degree of mineralization and depends on natural and anthropogenic factors such as the geology of the basin, the temperature, the vaporization of the water, the variation in the flow of the inflows which feeds the lake, the pollution by wastewater (Gouasmia and al., 2016; Hade, 2003; Benin Chrystelle, 2018). Waters are soft when the conductivity is lower than 500 $\mu \mathrm{s} / \mathrm{cm}$, and mineral when the conductivity is over $600 \mu \mathrm{s} / \mathrm{cm}(\mathrm{OBV}, 2013)$.

- The temperature: is a physical parameter necessary in the classification of the lakes and its daily and seasonal variation influences the other physico-chemical parameters such as the concentration in dissolved oxygen. The stratification and the upwelling of the waters of the lakes are based on this parameter of water.

During the survey, the measured values of the dissolved oxygen (in $\mathrm{mg} / \mathrm{l}$ and \%), the temperature $\left({ }^{\circ} \mathrm{C}\right)$, the $\mathrm{pH}$ and the electric conductivity $(\mu \mathrm{s} / \mathrm{cm})$ were recorded in a field notebook prior to their transcription in an Excel leaf. The survey covered a period starting from August 2018 to July 2019, 12 months in total.

\section{Data analysis}

The field data were exported from the Excel leaf to specific software of analysis. One part of the data was processed using the software STATSITICA and the analysis of main components (ACP) was done by mean of XLSTAT. The descriptive analysis allowed calculating the average, the standard deviation, the minimum, and the maximum of every parameter according the month, the phase, and the hours of sampling for the circadian cycle. The analysis of correlation between the parameters was made through ANOVA and allowed to compare the variability of the data between months, phases and circadian cycles.

The ACP helped to show the relationship between the environmental variables, and also to regroup the months according to the expression of these variables. 


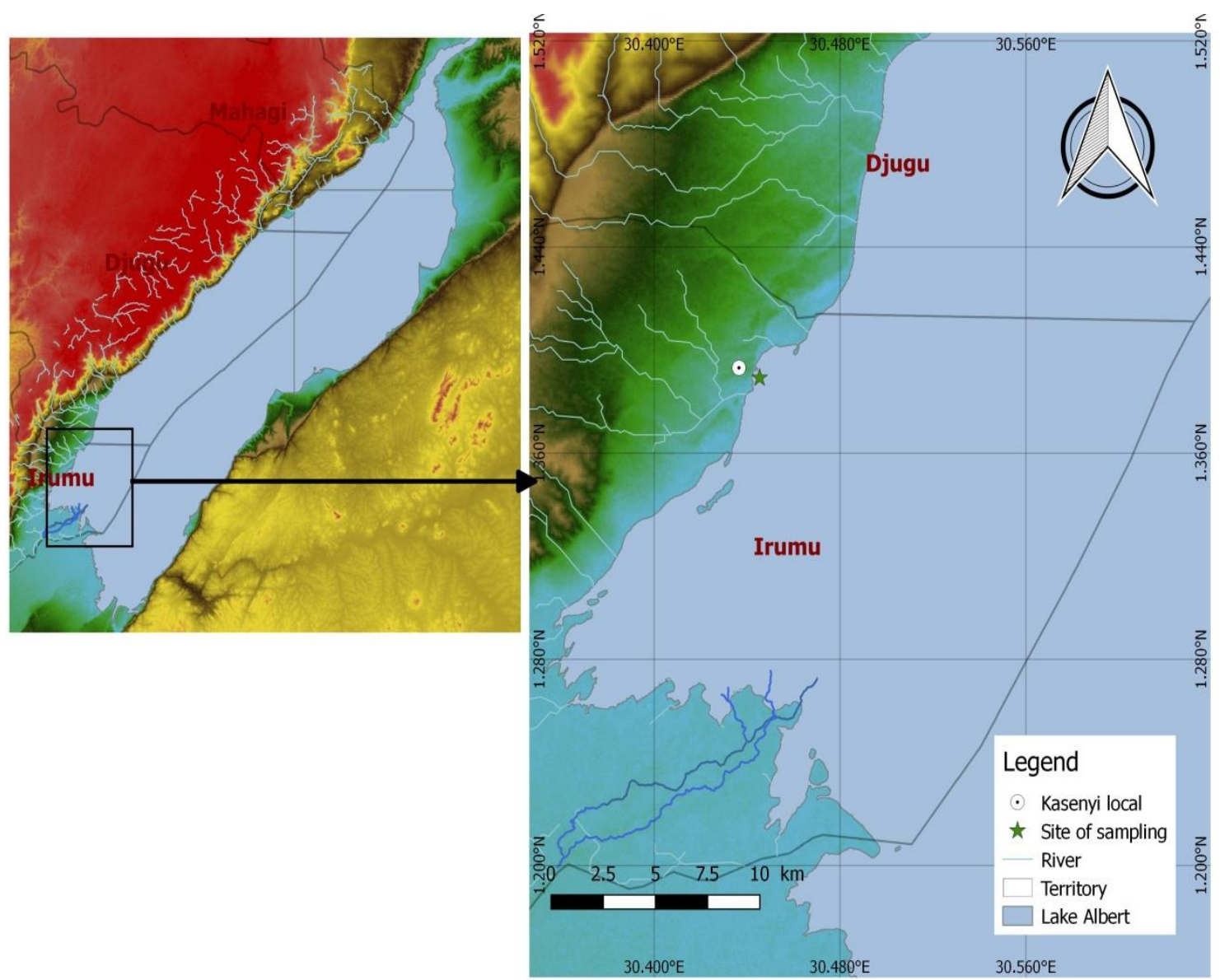

Figure 1: Localization of the sampling site for physico-chemical parameters.

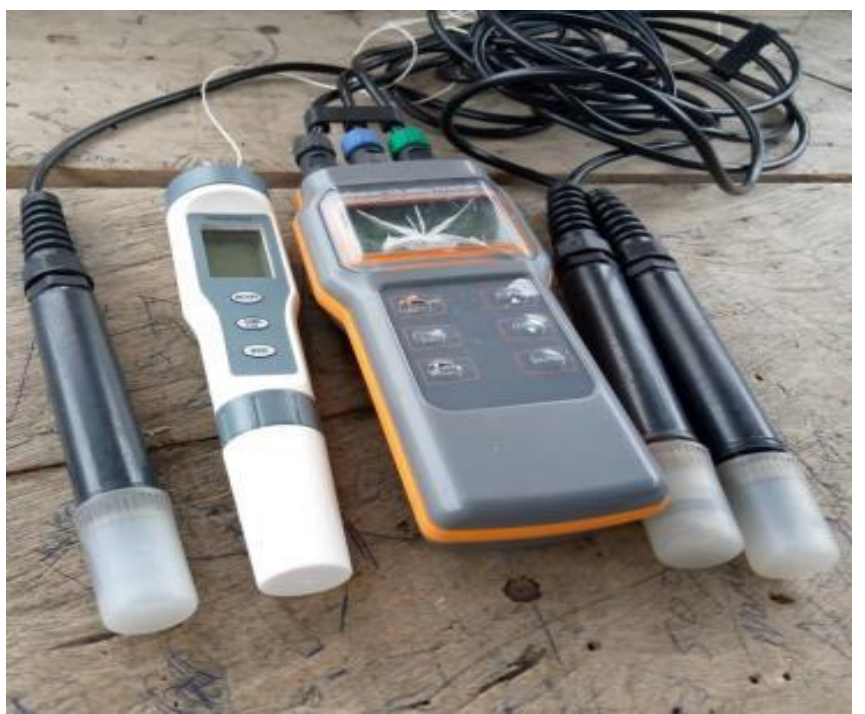

Figure 2: The multi-parameter device used. 


\section{RESULTS}

\section{Variability of studied parameters during 12 months}

At the sampling site, the temperature varied from 26.2 to $34.6{ }^{\circ} \mathrm{C}$, the average being of $29.07 \pm 1,24{ }^{\circ} \mathrm{C}$ (Table 1). Despite the dissolved oxygen concentration average being in the acceptable margin for the aquatic living being, it was observed certain variability ( $4.8 \pm$ $2.09 \mathrm{mg} / \mathrm{l}$ and $54.48 \pm 23.99 \%$ ) during one year. The $\mathrm{pH}$ average was good and slightly basic $(8.01 \pm 0.55)$, and the conductivity average was $631.65 \pm 6 \mu \mathrm{S} / \mathrm{cms}$.

The monthly averages of the studied parameters are given in the Table 2. The highest temperature was observed in April and the lowest in July. The concentration of dissolved oxygen in water was lower $(2.95 \pm$ $0.6 \mathrm{mg} / \mathrm{l})$ in April; but in terms of percentage saturation, it was rather lower in May (26.19 \pm $7.44 \%)$. The lowest conductivity was observed in June $(619.69 \pm 7.41 \mu \mathrm{S} / \mathrm{cms})$ followed by July $(627.44 \pm 4.32 \mu \mathrm{S} / \mathrm{cms})$. The $\mathrm{pH}$ varied during all months between $7.49 \pm 0.9$ (July) and $8.78 \pm 0.15$ (November). It was noted that all studied parameters varied significantly with months (Table 3).

\section{Comparison of parameters between the day and the night phases}

Table 4 shows the average values of the environmental variables taken in account in this study. The subdivision of the circadian cycle indicated that the difference was significantly noticeable $(\mathrm{F}=3.83$ and $9.75, \mathrm{p} \leq$ 0.05 ) for the dissolved oxygen between the day and the night phases (Table 5).

Although the temperature and the $\mathrm{pH}$ varied numerically between the two phases (slightly high temperature during the day with a lower $\mathrm{pH}$ than during the night), this difference remained non-significant.

Table 6 shows that during the sunrise, the temperature increased significantly in the same way with the concentration in dissolved oxygen and the conductivity of water. At night (Table 7), the significant link was observed only between the temperature and the electric conductivity of water.

\section{Evolution of parameters with regard to the circadian cycle}

While integrating the analysis of the parameter variations according to the hours of records, it was observed (Table 8) that the peaks of temperature and dissolved oxygen were gotten at around $15 \mathrm{H}\left(30.22 \pm 1.5^{\circ} \mathrm{C}\right.$ and $6.71 \pm 2,89 \mathrm{mg} / \mathrm{l})$ whereas during this time the $\mathrm{pH}$ was lower $(7.71 \pm 0.58)$ (Table 8$)$.

Figure 3 shows that at the sunrise at around $6 \mathrm{H}$, the temperatures were lower and started increasing during the day to reach the peak at around $15 \mathrm{H}$, and then they decreased. The same phenomenon was observed for the concentration of dissolved oxygen. However, as opposite to the above two parameters, the $\mathrm{pH}$ was higher during the night as compared to that of the day.

Only the temperature, dissolved oxygen and $\mathrm{pH}$ varies significantly over time as shown by the result in Table 9 .

The analysis of the main components (Figure 4) showed the quantum of $15 \mathrm{H}$ to 18 $\mathrm{H}$ to be characterized by a positive relation between temperature and conductivity contrary to the other portions of time. From $21 \mathrm{H}$ to $6 \mathrm{H}$ in the morning, the $\mathrm{pH}$ was the main distinctive factor from the rest of sampling hours.

During this circadian cycle, the sampling of $12 \mathrm{H}$ was characterized by a particular concentration of dissolved oxygen (in $\mathrm{mg} / \mathrm{l}$ and in percentage) and this parameter was in positive relationship with the temperature and the conductivity. It can be observed that the slice of $9 \mathrm{H}$ played buffer role between the day and the night phase. At this stage, it was difficult to discriminate the studied environmental factors.

The evolution of the parameters according to the months of sampling (Figure 5) showed that the months of April and May demarcated from other months in terms of temperature and $\mathrm{pH}$ whereas those of March, August, October and November rather showed a distinctive conductivity as compared to other months. It was also noticed that the dissolved oxygen was characteristic to the months of February, July and September. During the course of one year, when the temperature or the $\mathrm{pH}$ increased, it was observed that the 
concentration in oxygen decreased sensibly (especially in terms of percentage). For the discriminated months based on the concentration in dissolved oxygen (February, July and September), it was observed a decrease of the temperature and the $\mathrm{pH}$ of water.
The months that differentiated themselves from others based on the relatively high conductivity (March, August, October and November), were followed by a general increase of the water temperature. The other three remaining months (December, January and June) could not be discriminated by the studied environmental factors.

Table 1: Annual averages, minima and maxima values of physico-chemical parameters during 12 months of study.

\begin{tabular}{lccccccc}
\hline & N & Average & Minimum & Maximum & Scope & Variance & Standard deviation \\
\hline $\mathrm{T}\left({ }^{\circ} \mathrm{C}\right)$ & 192 & 29.07 & 26.20 & 34.60 & 8.40 & 1.55 & 1.24 \\
$\mathrm{DO}(\%)$ & 192 & 54.48 & 10.50 & 127.70 & 117.20 & 575.41 & 23.99 \\
$\mathrm{DO}(\mathrm{mg} / \mathrm{l})$ & 192 & 4.80 & 1.30 & 15.80 & 14.50 & 4.39 & 2.09 \\
$\mathrm{pH}$ & 192 & 8.01 & 6.20 & 9.00 & 2.80 & 0.31 & 0.55 \\
Conductivity $(\mu \mathrm{S} / \mathrm{cm})$ & 192 & 631.65 & 610.00 & 642.00 & 32.00 & 36.04 & 6.00 \\
\hline
\end{tabular}

Table 2: Monthly averages of physico-chemical parameters during the study period.

\begin{tabular}{lccccc}
\hline & Temperature & DO \% & DO $(\mathbf{m g} / \mathbf{l})$ & $\mathbf{p H}$ & Conductivity $(\boldsymbol{\mu S} / \mathbf{c m})$ \\
\hline August & $29.83 \pm 2.3$ & $51.97 \pm 22.8$ & $5.16 \pm 2.15$ & $7.51 \pm 0.24$ & $634.25 \pm 2.48$ \\
September & $28.33 \pm 0.6$ & $70.16 \pm 22.8$ & $5.66 \pm 1.62$ & $7.76 \pm 0.33$ & $635.31 \pm 2.55$ \\
October & $28.9 \pm 0.7$ & $72.41 \pm 16.39$ & $5.82 \pm 1.23$ & $8.14 \pm 0.7$ & $636.44 \pm 2.25$ \\
November & $29.54 \pm 0.9$ & $77.66 \pm 23.22$ & $6.2 \pm 1.71$ & $8.78 \pm 0.15$ & $634.36 \pm 3.16$ \\
December & $28.73 \pm 0.5$ & $56.19 \pm 16.87$ & $4.43 \pm 1.0$ & $8.45 \pm 0.4$ & $629.19 \pm 4.55$ \\
January & $28.58 \pm 0.7$ & $33.41 \pm 8.38$ & $4.85 \pm 3.92$ & $8.15 \pm 0.3$ & $631.06 \pm 5.22$ \\
February & $29.21 \pm 1.1$ & $65.77 \pm 17.36$ & $5.12 \pm 1.59$ & $7.63 \pm 0.4$ & $630.06 \pm 1.18$ \\
March & $29.52 \pm 1.6$ & $54.69 \pm 13.42$ & $4.74 \pm 1.76$ & $8.12 \pm 0.4$ & $635.13 \pm 2.96$ \\
April & $30.14 \pm 0.9$ & $38.27 \pm 9.33$ & $2.95 \pm 0.6$ & $8.11 \pm 0.2$ & $635.13 \pm 1.71$ \\
May & $29.89 \pm 0.9$ & $26.19 \pm 7.44$ & $4.09 \pm 1.85$ & $7.77 \pm 0.3$ & $631.75 \pm 5.84$ \\
June & $28.29 \pm 0.5$ & $31.14 \pm 7.39$ & $2.56 \pm 0.53$ & $8.15 \pm 0.2$ & $619.69 \pm 7.41$ \\
July & $27.91 \pm 0.5$ & $75.83 \pm 21.12$ & $6.01 \pm 1.63$ & $7.49 \pm 0.9$ & $627.44 \pm 4.32$ \\
\hline TsGrpes & $29.07 \pm 1.24$ & $54.47 \pm 23.99$ & $4.8 \pm 2.1$ & $8.01 \pm 0.6$ & $631.65 \pm 6.0$ \\
\hline
\end{tabular}

Table 3: Variance analysis of parameters in relationship with months.

\begin{tabular}{lcccccccc}
\hline & SC & Dl & MC & SC & dl & MC & F & p \\
\hline $\mathrm{T}^{\circ}$ & 91.59 & 11 & 8.326 & 204.35 & 180 & 1.135 & 7.334 & $2.6 \mathrm{e}^{-10}$ \\
$\mathrm{DO} \%$ & 59992.39 & 11 & 5453.853 & 49911.06 & 180 & 277.284 & 19.669 & $1.3 \mathrm{e}^{-25}$ \\
$\mathrm{DO} \mathrm{mg} / \mathrm{l}$ & 232.41 & 11 & 21.128 & 605.84 & 180 & 3.366 & 6.277 & $9.8 \mathrm{e}^{-9}$ \\
$\mathrm{pH}$ & 26.27 & 11 & 2.388 & 32.36 & 180 & 0.180 & 13.283 & $2.3 \mathrm{e}^{-18}$ \\
Conductivity $(\mu \mathrm{S} / \mathrm{cm})$ & 3911.31 & 11 & 355.573 & 2972.31 & 180 & 16.513 & 21.533 & $0.7 \mathrm{e}^{-27}$ \\
\hline
\end{tabular}


Table 4: Calculation of averages during the two phases.

\begin{tabular}{lcccccc}
\hline Phase & N & $\mathbf{T}^{\circ} \mathbf{C}$ & DO \% & DO $\mathbf{~ m g / l}$ & pH & Conductivity $(\boldsymbol{\mu S} / \mathbf{c m})$ \\
\hline Day (6h to 15h) & 96 & $29.18 \pm 1.34$ & $57.83 \pm 26.92$ & $5.26 \pm 2.32$ & $7.95 \pm 0.57$ & $631.39 \pm 6.57$ \\
Night (18h to 03h) & 96 & $28.96 \pm 1.13$ & $51.11 \pm 20.23$ & $4.34 \pm 1.73$ & $8.07 \pm 0.53$ & $631.92 \pm 5.39$ \\
\hline TsGrpes & 192 & $29.07 \pm 1.24$ & $54.48 \pm 23.99$ & $4.80 \pm 2.09$ & $8.0 \pm 0.55$ & $631.65 \pm 6.0$ \\
\hline
\end{tabular}

Table 5: Analysis of parameter variance during the two phases.

\begin{tabular}{lrrrrrrrc}
\hline & \multicolumn{1}{c}{ SC } & \multicolumn{1}{c}{ Dl } & \multicolumn{1}{c}{ MC } & \multicolumn{1}{c}{ SC } & \multicolumn{1}{c}{ Dl } & \multicolumn{1}{c}{ MC } & \multicolumn{1}{c}{ F } & p \\
\hline $\mathrm{T}^{\circ} \mathrm{C}$ & 2.319 & 1 & 2.319 & 293.6 & 190 & 1.5453 & 1.500507 & 0.222110 \\
$\mathrm{DO} \%$ & 2171.637 & 1 & 2171.637 & 107731.8 & 190 & 567.0095 & 3.829983 & 0.041808 \\
$\mathrm{DO} \mathrm{mg} / \mathrm{l}$ & 40.913 & 1 & 40.913 & 797.3 & 190 & 4.1965 & 9.749266 & 0.002074 \\
$\mathrm{Ph}$ & 0.676 & 1 & 0.676 & 58.0 & 190 & 0.3050 & 2.215184 & 0.138317 \\
Conductivity & 13.547 & 1 & 13.547 & 6870.1 & 190 & 36.1583 & 0.374655 & 0.541210 \\
$(\mu \mathrm{S} / \mathrm{cm})$ & & & & & & & &
\end{tabular}

Table 6: Correlation among parameters during the day phase ( $\mathrm{p}$-value $<0.05$ in red).

\begin{tabular}{lccccr}
\hline & $\mathbf{T}^{\circ} \mathbf{C}$ & DO \% & DO $\mathbf{~ m g} / \mathbf{l}$ & pH & Conductivity $(\boldsymbol{\mu S} / \mathbf{c m})$ \\
\hline $\mathrm{T}^{\circ} \mathrm{C}$ & & 0,077350 & 0,006966 & 0,105438 & 0,000377 \\
$\mathrm{DO} \%$ & & 0,000000 & 0,011234 & 0,013440 \\
$\mathrm{DO} \mathrm{mg} / \mathrm{l}$ & & & & 0,009219 & 0,023137 \\
$\mathrm{pH}$ & & & & & 0,918895 \\
Conductivity $(\mu \mathrm{s} / \mathrm{cm})$ & & & & & \\
\hline
\end{tabular}

Table 7: Correlation among parameters during the night phase ( $\mathrm{p}$-value $<0.05$ in red).

\begin{tabular}{cccccc}
\hline & $\mathbf{T}^{\circ}$ & $\mathbf{D O} \%$ & $\mathbf{D O} \mathbf{~ m g} / \mathbf{l}$ & $\mathbf{p H}$ & Conductivity $(\boldsymbol{\mu S} / \mathbf{c m})$ \\
\hline $\mathrm{T}^{\circ} \mathrm{C}$ & & 0,934007 & 0,117497 & 0,465342 & 0,000465 \\
$\mathrm{DO} \%$ & & 0,000000 & 0,271926 & 0,219527 \\
$\mathrm{DO} \mathrm{mg} / \mathrm{l}$ & & & 0,883725 & 0,095532 \\
$\mathrm{pH}$ & & & & 0,997670 \\
Conductivitéy $(\mu \mathrm{s} / \mathrm{cm})$ & & & & & \\
\hline
\end{tabular}

Table 8: Calculation of averages with regard to circadian cycle.

\begin{tabular}{lcccccc}
\hline Hour & $\mathbf{N}$ & $\mathbf{T}^{\circ} \mathbf{C}$ & $\mathbf{D O} \mathbf{~ m g / l}$ & $\mathbf{D O} \%$ & $\mathbf{p H}$ & Conductivity $(\boldsymbol{\mu} \mathbf{S} / \mathbf{c m})$ \\
\hline $6 \mathrm{H}$ & 24 & $28,26 \pm 0,76$ & $3,72 \pm 1,04$ & $41,25 \pm 17,32$ & $8,17 \pm 0,56$ & $631,83 \pm 5,42$ \\
$9 \mathrm{H}$ & 24 & $28,55 \pm 0,7$ & $4,51 \pm 1,45$ & $51,18 \pm 22,36$ & $8,09 \pm 0,53$ & $630,46 \pm 6,83$ \\
$12 \mathrm{H}$ & 24 & $29,69 \pm 1,22$ & $6,11 \pm 2,17$ & $67,95 \pm 28,88$ & $7,81 \pm 0,54$ & $631,04 \pm 7,29$ \\
$15 \mathrm{H}$ & 24 & $30,22 \pm 1,5$ & $6,71 \pm 2,89$ & $70,98 \pm 27,19$ & $7,71 \pm 0,58$ & $632,21 \pm 6,87$ \\
$18 \mathrm{H}$ & 24 & $29,74 \pm 1,22$ & $4,76 \pm 1,55$ & $55,78 \pm 20,62$ & $7,88 \pm 0,50$ & $632,5 \pm 5,68$ \\
$21 \mathrm{H}$ & 24 & $29,19 \pm 0,95$ & $5,06 \pm 2,18$ & $52,61 \pm 22,75$ & $8,07 \pm 0,53$ & $631,88 \pm 5,28$ \\
$0 \mathrm{H}$ & 24 & $28,86 \pm 0,84$ & $4,05 \pm 156$ & $50,83 \pm 21,57$ & $8,13 \pm 0,51$ & $631,71 \pm 5,26$ \\
$3 \mathrm{H}$ & 24 & $28,06 \pm 0,82$ & $3,48 \pm 1,12$ & $45,24 \pm 14,87$ & $8,18 \pm 0,55$ & $631,58 \pm 5,66$ \\
\hline
\end{tabular}




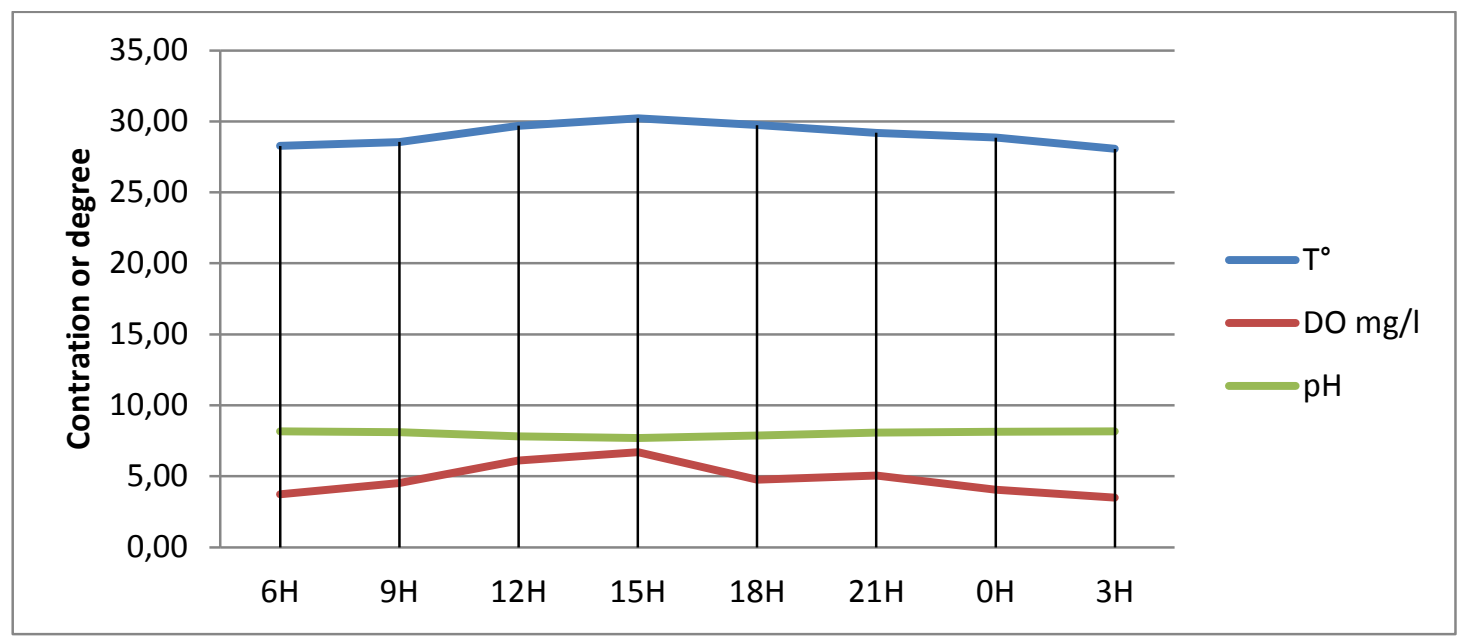

Figure 3: Curve of the evoluation of the $\mathrm{T}^{\circ}$, the $\mathrm{DO}$ and the $\mathrm{pH}$ during the circadian cycle.

Table 9: Analysis of parameter variance with regard to circadian cycle.

\begin{tabular}{lcccccccc}
\hline & SC & Dl & MC & SC & dl & MC & F & p \\
\hline $\mathrm{T}^{\circ} \mathrm{C}$ & 98,81 & 7 & 14,116 & 197,12 & 184 & 1,071 & 13,177 & 0,0000001 \\
$\mathrm{DO} \%$ & 17845,61 & 7 & 2549,373 & 92057,84 & 184 & 500,314 & 5,096 & 0,000026 \\
$\mathrm{DO} \mathrm{mg} / \mathrm{l}$ & 215,13 & 7 & 30,733 & 623,12 & 184 & 3,387 & 9,075 & 0,0000001 \\
$\mathrm{pH}$ & 5,48 & 7 & 0,783 & 53,15 & 184 & 0,289 & 2,712 & 0,010652 \\
Conductivity $(\mu \mathrm{S} / \mathrm{cm})$ & 69,99 & 7 & 9,999 & 6813,63 & 184 & 37,031 & 0,270 & 0,964861 \\
\hline
\end{tabular}

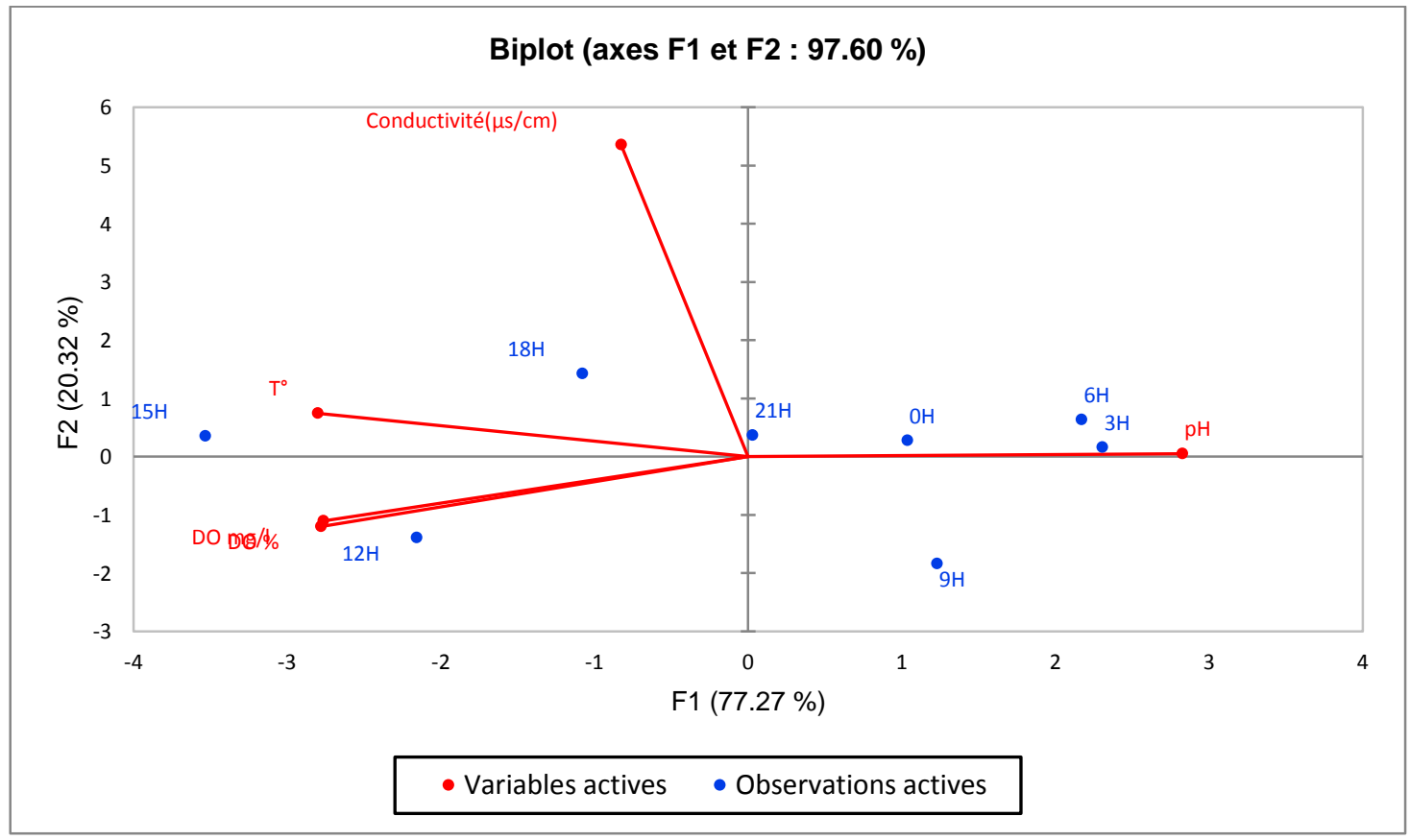

Figure 4: Main components of the parameter differences according to the circadian cycle. 


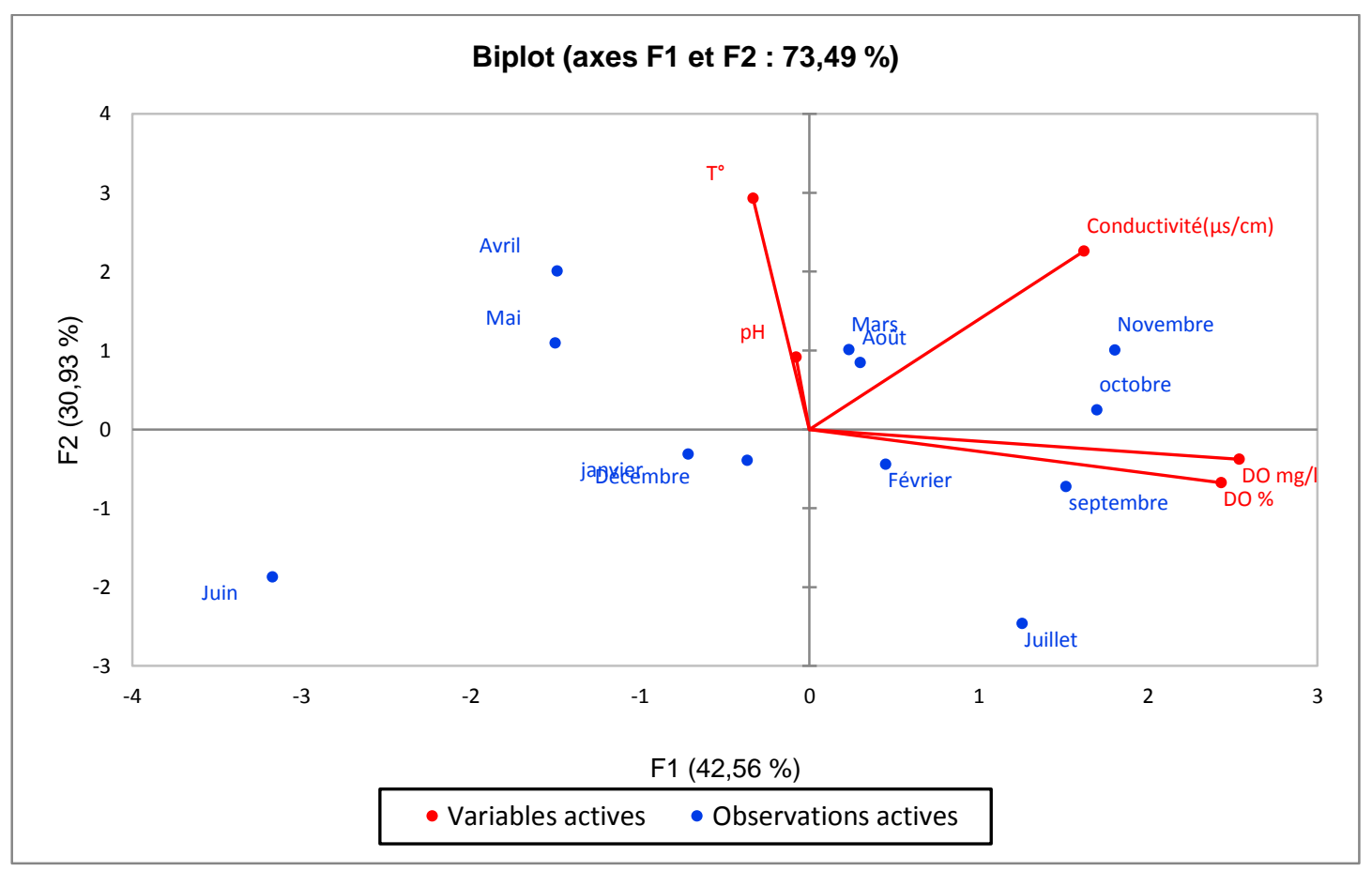

Figure 5: Main components of the parameter differences according to the months.

\section{DISCUSSION}

Temperature is a key factor in the biological process and regulates the growth of several aquatic species (Kadlec and Reddy, 2001).

. During the course of this survey, the temperature varied daily and monthly, with a yearly average of $29.07 \pm 1.24{ }^{\circ} \mathrm{C}$. It was higher in April $\left(30.14{ }^{\circ} \mathrm{C}\right)$ and lower in July $\left(27.91{ }^{\circ} \mathrm{C}\right)$.

Many authors (Hade, 2003; Atinkpahoun, 2018 ; Gouasmia et al., 2016) agree on the facts that when there is increase of the temperature, the ions influencing the determination of matter in suspension in water increase, with as consequence the increase of the water conductivity, whose value depends on the nature of the substratum and exogenous and endogenous contributions (Scheneider, 2001; Yapo Ossey et al., 2008; Tang et al., 2014). The average temperature of the Albert Lake was higher than that of the other three lakes found in the Eastern part of the DRC, in the Albertin rift. In the Tanganyika Lake, it varied between 23.5 to $25.0{ }^{\circ} \mathrm{C}$, but in the coastal zone, it was comprized between 24 and $27{ }^{\circ} \mathrm{C}$ (Ntakimazi, 2005; Sigels and Colter, 1996; Nyangya, 2013). About the Edouard Lake, it was about $26{ }^{\circ} \mathrm{C}$ (Ssentongo, 1987), and finally, in the Kivu Lake where the values were lower (23 to $24.5^{\circ} \mathrm{C}$ ) (Sarmanton, 2006). This difference would be due to the altitude on the one hand, (Lake Albert being around 610 meters above sea level) and the reproach with the equator on the other hand.

In the coastal part of the Albert Lake, the conductivity $(631.65 \pm 6 \mu \mathrm{S} / \mathrm{cms})$ was higher than what was reported by Nyangya (2013) in the same part of the Tanganyika Lake $(543.8 \pm 54.8 \mu \mathrm{s} / \mathrm{cms})$. Nevertheless, it was lower than that of the Edouard Lake (around $900 \mu \mathrm{s}$ ) which receives waters from the Semliki river (Ssentongo, 1987). This hinted at higher conductivity of the Semliki delta waters as compared to other parts of the lake.

This would be justified by the fact that the conductivity of Lake Edward is $900 \mu \mathrm{s} / \mathrm{cm}$ and that the water of the latter is spilled in the southern part of Lake Albert by the Semliki River. 
Based on the criteria of the quality of the water destined to aquaculture and the good function of an aquatic ecosystem such as a lake, the $\mathrm{pH}$ of 6.5 to 9 is better for the development of the aquatic biodiversity (Hade, 2003). The $\mathrm{pH}$ found during this survey was within this interval $(8.01 \pm 0.6$ of average). From the above findings, it appeared that the degradation process was accelerated and the lake was susceptible to be a lake with high primary productivity. In August 2005, WWF (2005) found a $\mathrm{pH}$ relatively higher (8.9) as compared to that gotten in this work $(7.51 \pm 0.24)$. However, the yearly averages were similar $(8.01 \pm 0.6)$.

Generally, in an aquatic ecosystem, when the temperature increases, the dissolved oxygen decreases (Figure 2). The lowest temperature was observed in July (27.91 \pm 0.5 ${ }^{\circ} \mathrm{C}$ ) while the concentration in dissolved oxygen was higher $(75.83 \pm 21.12 \%)$. However, this dissolved oxygen was $38.27 \pm$ 9.33\% in April whereas the temperature was higher $\left(30.14 \pm 0.9^{\circ} \mathrm{C}\right)$. The yearly average temperature $\left(29.07{ }^{\circ} \mathrm{C}\right)$ was similar to that reported by Lehman et al., in 1995 although their survey was done during the only month of March 1995.

Although the concentration in dissolved oxygen varied relatively through months, the observed averages (54.47\% and $4.8 \mathrm{mg} / \mathrm{l})$ classified the water of the Albert Lake in the category of good waters for the ichtyofauna, with regard to the requirements for species living in that lake and is higher than most waters with high primary and secondary productivity (Buhungu, 2018; Fermont, 2007). During the circadian cycle, it was noticed that all studied environmental factors varied daily except for the conductivity whose variability was non-significant (Table 9).

Figure 3 shows that at the sunrise, the temperature of water increased to reach the peak at around $15 \mathrm{H}$ and decreased thereafter. A similar tendency was observed for the concentration in dissolved oxygen. However, the $\mathrm{pH}$ showed an inverse tendency in relation with the two precedents parameters. This tendency seemed to be in contradiction with the theory which stipulates that when the temperature increases, the concentration in dissolved oxygen decreases.

The analysis of the day and night phases (Tables 4, 5 and 6) shows that the temperature was not the factor influencing the difference of the dissolved oxygen concentration observed between the two phases. In report published by Zuntz (1900) cited by Secondat (1951), it was said that in summer, in the pool having a rich vegetation, the concentration in dissolved oxygen increased during the day reaching up to $22 \mathrm{~cm}^{3} /$ litre and decreased at night till 2 $\mathrm{cm}^{3} /$ litre. This demonstrated that the explanation about the variation of the dissolved oxygen concentration followed the same understanding in the Albert Lake. In the coastal zone where sampling was done, the increase of the dissolved oxygen concentration was probably due to the process of photosynthesis during the day with as consequence the reduction of the water $\mathrm{pH}$. During the night, there was no photosynthesis process by absence of the sun light, the oxygen was then consumed by the primary and secondary producers, which had as consequence the reduction of the dissolved oxygen concentration and the increase of water $\mathrm{pH}$. The dissolved oxygen concentration in surface waters of the coastal part of the Albert Lake was lower $(4.8 \pm 2.1 \mathrm{mg} / \mathrm{l})$ following high primary and secondary productivity as compared to that of the Tanganyika Lake (6.34 $\pm 2.48 \mathrm{mg} / \mathrm{l}$ ) reported by Nyangya (2013). However, it remains higher than that found in waters with high eutrophication of $1.879 \mathrm{ml} /$ $\mathrm{g}$, value found by Affloua et al. (2019).

\section{Conclusion}

The working of an ecosystem is based on the abiotic and biotic conditions of the media. Our survey was done on the circadian and the yearly evolution of four physicochemical parameters of the Albert Lake waters allowing to make a first appreciation of the living conditions of the fish. Of all studied parameters, the conductivity of water underwent fewer fluctuations during the months, and its daily variation was less affected by the temperature, the $\mathrm{pH}$ and the dissolved oxygen concentration of water. In the 
coastal part of the lake where the survey was done, the variation of the dissolved oxygen concentration (\% and $\mathrm{mg} / \mathrm{l})$ was independent of the circadian variation of the temperature, but rather depended on the activity of the primary producers (the action of the photosynthesis) although it was observed a slight difference of temperature between the day and the night phases. This also explained the increase water $\mathrm{pH}$ at night (21 $\mathrm{H}$ to $6 \mathrm{H}$ morning).

The analysis of the main components allowed determining that, all along of the year, April and May were characterized by the highest temperature, which was favorable for high conductivity of waters resulting in a decrease of the dissolved oxygen concentration. The months with higher dissolved oxygen concentrations had slightly lower temperatures (February, July and September).

\section{COMPETING INTERESTS}

The authors declare that they have no competing interests.

\section{AUTHORS' CONTRIBUTIONS}

KDC organized the data collection, analyzed and wrote the article manuscript; LJK contributed to the data collection; BAK and $\mathrm{J}$-CM guided the tests and corrected the manuscript.

\section{ACKNOWLEDGMENTS}

This work was carried out with serious assistance from the agents of the environment and agriculture services on the one hand and that of the local chief of Kasenyi for giving us housing and security our tools for collecting data in the field.

\section{REFERENCES}

Atinkpahoun N, Soclo H, Pons M, Leclerc J-P. 2018. Physico-chemical characterization of domestic wastewaters in the "VieNouvelle" agglomeration, Cotonou. Int. J. Biol. Chem. Sci., 12(1): 542-557.

Buhungu S, Montchowui E, Barankanira E, Sibomana C, Ntakimazi C, Bonou CA. 2018. Caractérisation spatio-temporelle de la qualité de l'eau de la rivière
Kinyankonge, affluent du Lac Tanganyika, Burundi. Int. J. Biol. Chem. Sci., 12(1): 576-595.

Fermon Y. 2007. La clé de détermination des familles de poissons du lac Albert, Paris, $20 \mathrm{p}$.

Hecky RE, Kling HJ. 1987. Phytoplankton ecology of the great lakes in the rift calley of Central Africa. Arch. Hydrobiol. Beih. Ergebn. Limnol, 25: 197-228.

Hade A. 2003. Nos Lacs. Les Connaître pour Mieux les Protéger. Editions Fides.

Kadlec RH, Reddy KR. 2001. Temperature effects in treatment wetlands. Water Environment Research, 73: 543-557.

Kpidi YH, Yapo OB, Ballet TG, Ohou-Yao MJ. 2017. Variation journalière de la qualité physico-chimique de l'eau du lac M'Koa de Jacqueville (Côte d'Ivoire). Int. J. Biol. Chem. Sci., 11(2): 901-910.

Gboko AJ, Akobe AC, Aka AM, Aka CA, Kouame AF, Adou KN, Yapo OB, Monde S, Aka K. 2019. Etat d'eutrophisation de la lagune continentale Ono (Bonoua sud-est de la Côte d'Ivoire) dans un environnement agro-industriel durant la crue du fleuve Comoé. Int. J. Biol. Chem. Sci., 13(6): 2942-2958.

Gouasmia G, Amarouyacha M, Frihi H, Kara MH. 2016. Physico-chimie de trois lacs salés permanents de la vallée d'Oued Righ (Sahara septentrional, Algérie nordest). Revue d'Ecologie (Terre et Vie), 71(4): 330-341.

Laboulle H. 2010. Etude du lac Bourg-d'Hem. Creuse-France, $42 \mathrm{p}$.

Lehman JT, Litt AH, Mugidde R, Lehman DA. 1995. Nutrients and plankton biomass in the rift lake sources of the white Nile: Lake Albert and Edward. Environmental change and response in East African lakes. Kluwer Academic Publishers, 15: 157-172.

Moater F, Meybeck M, Poirel A. 2009. Variation journalière de la qualité des rivières et son incidence sur la surveillance à long terme/ exemple de la Lavie moyenne. La Houille blanche. Revue International de l'Eau; EDP Science, 4: 91-99. 
Montgomery MA, Elimelech M. 2007. Water and sanitation in developping countries: Including health in the equation. Environmental Sciences and Technology, 41(1): 17-24.

Ntakimazi G. 2005. Le rôle dans les écotones terre/eau dans la diversité biologique et les ressources du lac Tanganyika. Projet UNESCO/MAB/DANIDA 510/BDI/40, 1991-1994, Rapport final, $84 \mathrm{p}$.

Nyangya BL, Isumbusho P. 2013. Essai d'évaluation de l'influence des activités anthropiques sur la physico-chimie, la composition et l'abondance du plancton et des macroinvertébrés du littoral du lac Tanganyika (cas des zones littorales le long de Bujumbura Burundi et Uvira en RD Congo), $87 \mathrm{p}$.

OBV (Organisation des bassins versants du Nord-Est du Bas-saint-Laurant). 2013. Caractérisation du lac de cœur, 'Rapport $\mathrm{du}$ projet sur la protection et la mise en valeur des ressources naturelles par la sensibilisation et la responsabilisation des usagers actuels et futurs des bassins versants forestiers de la MRC de Matane, $22 \mathrm{p}$.

Sabater S, Armengo J, Comes E, Sabater F, Urrizalqui I, Urrutia I. 2000. Biomass in a disturbed Altantic river: Water quality relationship and environmental implications. Sciences Total Environ, 263: 185-195.

Sarmanton H. 2006. Ecologie du phytoplancton du lac Kivu (Afrique de l'Est). PhD Thèse, Université de FUNDPNamur, $147 \mathrm{p}$.

Secondat M. 1951. Les variations de la température et de la concentration en oxygène dissous des eaux lacustres et des eaux courantes. Leur retentissement sur la distribution des poissons, $105 \mathrm{p}$.

Scheneider G. 2001. Boues de curage des cours d'eau. Courier de l'environnement de l'INRA, 4S : 146-147.

Spigel RH, Coulter GW. 1996. Comparison of hydrology and physical limnology of East African great lakes: Tanganyika, Malawi, Victoria, Kivu and Turkana (With reference to some North American great lakes). In The Limnology, Climatology and Paleoclimatology of the East African Lakes, John TC, Odada EO (Eds). Gordon and Breach Publishers: Amsterdam; 103139.

Ssentongo GW. 1987. Projet PPEC exploitation des pêcheries et gestion rationnelle des lacs Edouard et Mobutu/Albert, $23 \mathrm{p}$.

Tang Wu X, Dai MX, Chai P. 2014. Phosphorus storage; dynamic and absorption characteristics for sediment from drinking water source reservoir and its relation with sediment compositions. Ecological Engineering, 64 : 276-284.

Villeneuve V, Légaré S, Painchaud J, Vincent W. 2006. Dynamique et modélisation de l'oxygène dissous des rivières. Revue des Sciences de l'Eau, 19(4): 259-274.

Wetzel RG. 2001. Limnology Lakes and River Ecosystem ( $3^{\mathrm{e}}$ Edn). Academic Press: San Diego; $1006 \mathrm{p}$.

Wetzel RG, Likens GE. 2000. Limnological Analysis $\left(2^{\mathrm{e}} \mathrm{Edn}\right)$. Springer-verlag: NewYork; $429 \mathrm{p}$.

WWF. 2005. Lake Albert Eastern Catchment management initiative, Uganda. Baseline study on water quality monitoring, August, September. Report projet $\mathrm{n}^{\circ}$ UGA-04/193, 0028/5010. 117 p. 